\title{
Effect of Supplementation of Different Concentrate Rations on Weight Gain, Milk Yield, and Composition of Cross Bred Buffalo Cows
}

\author{
Kanakkahewage $\mathrm{M}^{1}$, Jasinghe $\mathrm{O}^{1}$, Sujani $\mathrm{S}^{2}$, Seresinhe $\mathrm{T}^{2}$ \\ ${ }^{1}$ Department of Animal Production and Health, Sri Lanka \\ ${ }^{2}$ Department of Animal Science, Faculty of Agriculture, University of Ruhuna \\ Mapalana, Kamburupitiya 81100, Sri Lanka \\ thakshas@ansci.ruh.ac.lk; profthakshala@yahoo.com
}

\begin{abstract}
A field experiment was conducted to evaluate the effect of three concentrate supplements with different metabolizable energy (ME) levels on weight gain, milk yield and composition in milking buffalos. Sixteen Murrah $\times$ non-descriptive crossed bred milking cows $(720 \pm 50 \mathrm{~kg})$ were used. Animals in treatment 1 (T1) were fed only with forages while animals in other three treatments were given $90 \%$ forages $+10 \%$ concentrate. The three treatments were Commercial concentrate feed (T2) (ME (Kcal/kg): $2500 \pm 0.75)$, farm made concentrate feed (T3) (ME (Kcal $/ \mathrm{kg}$ ): 2733.25 \pm 2.32 ) and experimental feed (T4) (ME (Kcal/kg): 2933.03 \pm 2.15$)$. Experimental design was a Randomized Complete Block Design (RCBD) with four treatments and four replicates. Forage intake was reduced, when feeding concentrate rations with high energy and $\mathrm{CP}$, recording highest reduction with T4 followed by T3 and T2. Significant enhancement $(\mathrm{P}<0.05)$ and also highest values of weight gain, milk yield, fat, protein, and solid non-fat were observed with T4. Conclusion can be drawn that, higher milk yield with better composition could be obtained by feeding high energy rations formulated with low cost, locally available ingredients.
\end{abstract}

Key Words: Energy Supplement, Milk Yield, Buffalo, Weight Gain

\section{INTRODUCTION}

The rearing of domestic water buffaloes (Bubalus bubalis) play a vital role in the cereal-dominated agricultural economy of the tropical developing countries like Sri Lanka. In 2013, the population of buffaloes in Sri Lanka was around 0.4 million and their contribution for total milk production was approximately $18.25 \%$ producing 61.7 million liters (Department of Census and Statistics 2013). In an economical perspective, buffalo farming has maximum economic significance to farmers due to its milk richness, suitability of making curd, butter, butter oil, soft cheese, condensed or evaporated milk, ice cream, yogurt, etc. It is high in fat and total solids, which gives it a rich flavor. It therefore often brings higher prices than cow's milk. With the emerging concerns of health aspects and rising income the taste and preference to daily products have changed globally and nationally. Referring to the present scenario of milk production in Sri Lanka, still only $30 \%$ of the self-sufficiency has acquired and the deficit of $70 \%$ accounts for imported milk products. Improving the status of buffalo farming with proper feeding, breeding and management is obviously a solution with very high potential to meet the national demand for milk.

As previous findings suggest intake and digestibility of forage affected by the quality of the forage and the type and level of supplementation. (Bowman \& Sanson 1996). Generally, buffalo farmers in the Southern zone of the country mainly involve with conventional feeding systems and farmers are unaware or not concern about the quality of forages and roughages and about the importance of supplementary feeding. Through supplementary feeding, animal can be provided with nutrients which are deficient in conventional feedstuffs. Most of the conventional feedstuffs including fodder grasses and 
rice straw are deficit in energy and protein and more specifically they are low in digestibility which suppresses the animal's optimum production efficiency. Hence this study was conducted to disclose the effect of three different types of supplementary feeds including a commercial concentrate, an on-farm diet and an experimental concentrate supplement on yield and composition of milk.

\section{MATERIAL AND METHODS}

\section{Experimental site, design, and treatments}

A field experiment was conducted at Harischandra Farm, Thudawa, Matara, during the period of May to August 2012 consisted with eight weeks of field experiment. The farm is situated in the low country wet zone of Sri Lanka (Matara District).

The experimental design was a Randomized Complete Block Design (RCBD) with four treatments and four blocks based on weight of the animals (replicated) including 16 animals. Buffaloe cows were randomly allocated to four treatments. Following feed rations were supplied during the experimental period.

$$
\begin{array}{ll}
\text { T1 (control) } & =100 \% \text { Fodder* }(\mathrm{F})(3 \% \text { of the body weight }(\mathrm{BW})) \\
\mathrm{T} 2 & =(2.7 \text { of BW\% F })+(0.3 \% \text { of BW commercial concentrate feed }) \\
\mathrm{T} 3 & =(2.7 \text { of BW\% F })+(0.3 \% \text { of BW farm made concentrate feed }) \\
\mathrm{T} 4 & =(2.7 \text { of BW\% F })+(0.3 \% \text { of BW experimental concentrate feed })
\end{array}
$$

All feeds were supplied in dry matter basis as a percentage of body weight. ${ }^{*} \mathrm{CO}_{3}$ - hybrid Napier (Pennisetum purpureum) (Average nutritional composition on dry matter basis, crude protein: $15.5 \pm 0.72 \%$, crude fat: $6.55 \pm 0.49 \%$, organic matter: $89.35 \pm 1.62$, crude fibre: $7 \pm 1.42)$.

The composition of the concentrate feeds used in three treatments is given in the results and discussion.

All feed samples were analyzed for energy, dry matter, crude protein and crude fiber in the laboratory of the Veterinary Research Institure, Gannoruwa.

\section{Experimental animal}

Sixteen (16) Murrah $\times$ non-descriptive crossed bred milking buffalo cows in mid lactation with average weight of $749.58 \mathrm{~kg} \pm 15.27$, daily milk yields of $6.75 \mathrm{~L} \pm 0.54$ and parity of $3.5 \pm 0.25$ were selected for the experiment.

\section{Feeding procedure}

Four animals in treatment 1(T1) were fed only with forages while animals in other three treatments were given, $90 \%$ forage $+10 \%$ concentrates. All animals were provided with a mineral mixture (composition per $\mathrm{kg}$, calcium: $185.2 \mathrm{~g}$, phosphorous: $79.0 \mathrm{~g}$, sodium: $92.8 \mathrm{~g}$, magnesium: $13.6 \mathrm{~g}$, copper: $1.1 \mathrm{~g}$, zinc: $61.0 \mathrm{~g}$, manganese: $5.3 \mathrm{~g}$, iodine: $68.0 \mathrm{mg}$, cobolt: $21.0 \mathrm{mg}$, selenium: $45.0 \mathrm{mg}$ ) and ad-libitum water. The feeding was done is a manner that one animal was getting one treatment throughout the whole experimental period.

Above feeding program was continued for four consecutive weeks while first three weeks of the whole period were considering as the adaptation period and the last the $4^{\text {th }}$ week was the sampling period. 


\section{Measurements and data collection}

Feed intake was recorded during the sampling period for seven days and calculating the difference between feed offered and refusals. Morning and evening milk yield were recorded during the experimental period (for seven days) and samples were taken each day to determine the milk composition. Milk samples were analyzed to determine fat percentage (Gerber method), crude protein (Kjeldhal method), Solid non-fat using the standard methods.

At weekly intervals, the body weights of buffalos were measured with the use of a waist band. The weights were corrected by using the regression equation, which has been developed by Seresinhe \& Pathirana (2006).

$$
\mathrm{Y}=-6.4288+0.861 \mathrm{X}
$$

Y: Corrected weight gain; X: Weight obtained by the waist band

\section{Analysis of milk samples}

Gerber method for the analysis milk fat, Kjeldahl method for nitrogen and gravimetric method for total solid were used.

\section{RESULTS AND DISCUSSION}

The proximate composition of energy concentrate supplements are presented in Table 1 and formulated feed which used for T4 has the highest energy content followed by Harischandra feed (T3) and Super feed (T2) (Figure 1).

Table 1. Proximate composition of concentrate rations

\begin{tabular}{lcccc}
\hline \hline Feed type & Energy $(\mathrm{kcal} / \mathrm{kg})$ & DM \% & Crude protein (\%) & Crude fiber (\%) \\
\hline $\begin{array}{l}\text { Commercial } \\
\text { concentrate }\end{array}$ & $2,500 \pm 0.75^{\mathrm{a}}$ & $90.05 \pm 0.73$ & $16.25 \pm 1.03^{\mathrm{a}}$ & $10.45 \pm 0.37^{\mathrm{a}}$ \\
$\begin{array}{l}\text { Farm made } \\
\text { concentrate }\end{array}$ & $2,733.25 \pm 2.32^{\mathrm{b}}$ & $89.53 \pm 0.51$ & $21.26 \pm 0.89^{\mathrm{b}}$ & $9.70 \pm 0.93^{\mathrm{a}}$ \\
$\begin{array}{l}\text { Experimental } \\
\text { concentrate* }\end{array}$ & $2,933.03 \pm 2.15^{\mathrm{c}}$ & $89.83 \pm 0.38$ & $15.29 \pm 0.67^{\mathrm{a}}$ & $14.73 \pm 0.16^{\mathrm{b}}$ \\
\hline
\end{tabular}

*Ingredient composition was $33 \mathrm{~kg}$ of rice bran, $50 \mathrm{~kg}$ of black gram husk and $17 \mathrm{~kg}$ of poonac for $100 \mathrm{~kg}$ of experimental concentrate
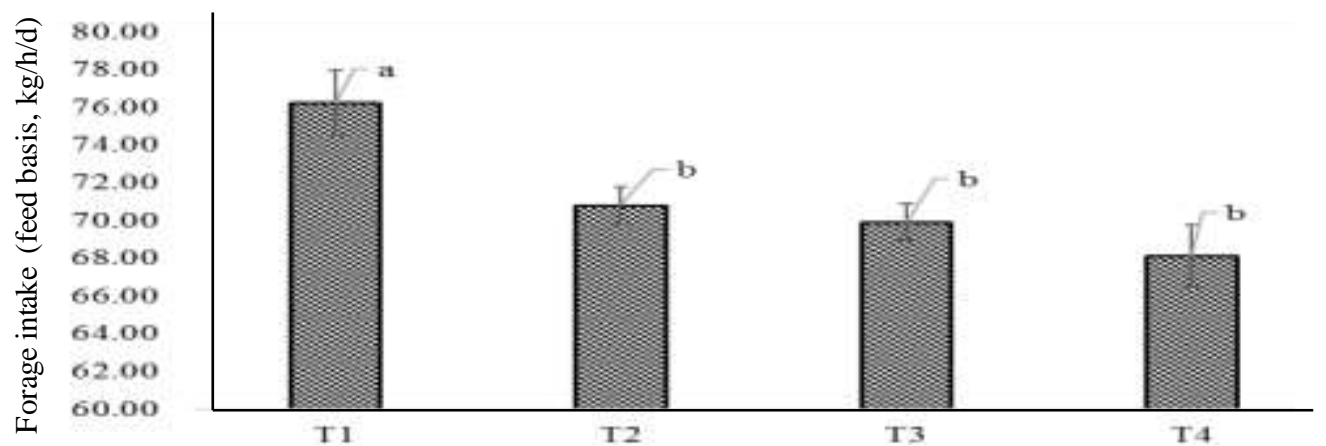

Data are average values of four replicates; Different letters indicate the significant difference at $\mathrm{P}<0.05$

Figure 1. Daily forage intake (fed basis) of buffalo cows in four groups 
The highest forage intake was observed with buffalo cows in T1 followed by buffalos in T2, T3, and T4. The average daily forage intake of buffalo cows in T1 was significantly higher than the concentrate supplemented groups.

Table 2. Total weight gain (g/head) in 28 days and milk yield $(\mathrm{kg} / \mathrm{d} / \mathrm{head})$ in response to the supplementation of energy concentrates

\begin{tabular}{lcc}
\hline \hline Treatment & Total weight gain $(\mathrm{g} / \mathrm{head})$ & Milk yield $(\mathrm{kg} / \mathrm{d} / \mathrm{head})$ \\
\hline T1 & $200 \pm 43^{\mathrm{a}}$ & $6.3 \pm 0.17^{\mathrm{a}}$ \\
T2 & $433 \pm 29^{\mathrm{b}}$ & $6.5 \pm 0.18^{\mathrm{a}}$ \\
T3 & $966 \pm 33^{\mathrm{c}}$ & $7.1 \pm 0.12^{\mathrm{b}}$ \\
T4 & $1,533 \pm 31^{\mathrm{d}}$ & $7.8 \pm 0.13^{\mathrm{c}}$ \\
\hline
\end{tabular}

Values are means of four replicates \pm SE values in a same column with different superscripts are significantly different at the $\mathrm{P}<0.05$

Table 3. Milk composition in response to the supplementation of energy concentrates

\begin{tabular}{lccc}
\hline \hline \multirow{2}{*}{ Treatment } & \multicolumn{3}{c}{ Milk composition $(\%)$} \\
\cline { 2 - 4 } & Milk fat & Solid non-fat & Milk protein \\
\hline T1 & $4.20 \pm 0.15^{\mathrm{a}}$ & $7.95 \pm 0.09^{\mathrm{a}}$ & $2.36 \pm 0.07^{\mathrm{a}}$ \\
T2 & $5.40 \pm 0.12^{\mathrm{b}}$ & $8.49 \pm 0.05^{\mathrm{b}}$ & $3.29 \pm 0.07^{\mathrm{b}}$ \\
T3 & $5.76 \pm 0.10^{\mathrm{c}}$ & $8.54 \pm 0.10^{\mathrm{b}}$ & $4.09 \pm 0.10^{\mathrm{c}}$ \\
T4 & $6.95 \pm 0.18^{\mathrm{d}}$ & $8.73 \pm 0.20^{\mathrm{c}}$ & $4.33 \pm 0.09^{\mathrm{d}}$ \\
\hline
\end{tabular}

Values are means of four replicates \pm SE values in a same column with different superscripts are significantly different at the $\mathrm{P}<0.05$

The highest body weight gain was observed with buffalo cows in T4 followed by buffalos in T3, T2, and T1 (Table 2). The highest daily milk yield of $7.8 \mathrm{~kg}$ was reported with T4 whilst lowest was reported with $\mathrm{T} 1$ and $\mathrm{T} 2$ (Table 2). The highest percentages of milk fat, solid non fat and protein were observed with T4 followed by T3, T2, and T1 (Table 3).

Buffaloes have high efficiency of feed utilization when fed on forages. However results have shown that when buffaloes were fed with forages and concentrate rations the average forage intake decreased significantly (Figure 1). The present result is supported by the findings of Jabbar et al. (2009) who observed that dry matter intake was significantly reduced with the increasing energy content of the concentrates.

Upon the supplementation of concentrates the weight gain of buffaloes enhanced significantly. If it was possible to take longer period to test parameters like weight gain of buffaloes, the difference observed might be more significant. In contrast to the present results Ballard et al. (2001) have reported that that energy supplementation during pre and post partum does not have any significant effect on body condition score or weight gain of the animals.

It was shown that when feeding forages with high quality concentrate rations, milk yields increased. Feeding of balanced ration individually had increased milk production but it's impact was increased when fed with high quality ration. The nutrient supplementation may lower stress during early lactation, and this may be the reason for significant increase in milk yield of the present study. The increase in yield suggests that supplementation had a positive effect on milk production by increasing the body reserves, which were mobilized for development of extra milk secretary tissues during lactation. 
Seresinhe et al. (2012) and Gaafar et al. (2009) reported significantly enhanced milk production upon the supplementation of energy concentrates which is allied with present results.

As theory implies, supplementing a nutritionaly balanced ration with a high amount of dry matter could increase the amount of solids in milk. The increment of SNF is directly proportional to the increment in metabolic energy supplied by the supplement and also feeding extra energy will often increase the SNF of milk. Comparing to the present study results, Faruque \& Hossain (2007) observed no changes in milk yield but the significant improvement of milk constituents upon supplementation of energy concentrates.

\section{CONCLUSION}

It can be concluded that supplementation of lactating buffalo cows with concentrates of increasing levels of energy could lead to better weight gains, milk yield and composition.

\section{REFERENCES}

Ballard CS, Mandebvu P, Sniffen PJ, Emanuele SM, Carter MP. 2001. Effect of feeding an energy supplement to dairy cows pre and post-partum on intake, milk yield and incidence of ketosis. Anim Feed SciTech. 93:55-69.

Bowman JGP, Sanson DW. 1996. Starch or fiber based energy supplements for grazing ruminants. In: Judkins MB, McCollum FT, editors. Proceedings $3^{\text {rd }}$ Grazing Livestock Nutrition Conference. Rapid City (US): Corona Range and Livestock Research Center. p. 118-135.

Department of Census and Statistics. 2013. Livestock population statistics. Colombo (Sri Lanka): Department of Census and Statistics.

Faruque MO, Hossain MI. 2007. The effect of feed supplement on the ieldy and composition of buffalo milk. Ital J Anim Sci. 2:488-490.

Gaafar HM, Mohi El-Din AI, Basiuoni AMAI, El-Riedey KFAI. 2009. Effect of concentrate to roughage ratio and baker's yeast supplementation during hot season on performance of lactating buffaloes. Slovak J Anim Sci. 42:188-195.

Jabbar M, Ahmad I, Pasha T, Abdullah M, Riffat S. 2009. Production performance of lactating Nili-Ravi buffaloes under the influence of bovine somatotrophic hormone with varying level of dietary energy. In: Proceedings of $6^{\text {th }}$ Asian Buffalo Congress. Lahore, Pakistan, 27-30 October 2009. p. 30.

Seresinhe T, Shamen HJD, Manawadu A, Marapana RAUJ. 2012. Effects of supplements on milk nitrogen efficiency of buffalo cows. J Anim Plant Sci. 22:200-204.

Seresinhe T, Pathirana KK. 2006. Effect of feeding rice straw and supplements on the performance of cattle under small farmer conditions. Trop Agric Res Ext. 9:131-142. 